Розділ III. Історичні та порівняльні аспекти в теорії і практиці духовно-інтелектуального виховання й навчання

\title{
РОЛЬ ПЕДАГОГІЧНОЇ ПРАКТИКИ У ПІДГОТОВЦІ МАЙБУТНЬОГО ВИКЛАДАЧА МИСТЕЦТВ
}

\section{Ткаченко Т. В.}

доктор педагогічних наук, професор, професор кафедри теорії та методики мистецької освіти Харківського національного університету мистецтв ім. І. П. Котляревського, м. Харків, Україна

У роботі розглянуто важливу роль педагогічної практики для підготовки майбутніх викладачів мистецьких дисциплін, ї̈ принџипи та закономірності. Установлено, що успішність підготовки студентамузиканта до педагогічної діяльності залежить від формування його духовних ичінностей, професійно-педагогічної культури, методичноі компетентності, інтелектуального розвитку, здатності до рефлексії.

Ключові слова: педагогічна практика, викладач, професійна педагогічна культура, творчий стиль, педагог-музикант.

The paper considers the important role of pedagogical practice for the training of future teachers of art disciplines, its principles and patterns. It is established that the success of preparing a student musician for pedagogical activities depends on the formation of his spiritual values, professional and pedagogical culture, methodological competence, intellectual development, ability to reflect.

Keywords: pedagogical practice, teacher, professional pedagogical culture, creative style, music teacher.

Педагогічна практика є важливою і необхідною частиною одного з основних напрямів діяльності студентів.

Мета дисципліни спрямована на підготовку студента до виконання професійних обов'язків педагога-музиканта на якісно високому рівні. Засвоєння студентами практичних навичок в обсязі, необхідному для успішної діяльності педагога.

Основні завдання вивчення дисципліни полягають у:

- набутті досвіду викладання фахових предметів у закладах вищої освіти мистецько-педагогічного спрямування;

- формуванні вмінь ведення наукових досліджень (діагностика педагогічних явищ та апробація результатів дослідної роботи);

- збагаченні та поглибленні теоретико-методологічних і методичних знань у процесі навчально-виховної роботи зі студентами; 
- удосконаленні комплексу практичних умінь та їх застосуванні у конкретних педагогічних ситуаціях у відповідності до форм і видів роботи зі студентською аудиторією;

- оволодінні досвідом використання на практиці інноваційних педагогічних технологій та сучасних методик навчання;

- формуванні у магістрів морально-етичних якостей викладача вищої школи;

- розвитку потреби у самоосвіті, самовихованні, саморозвитку;

- формуванні індивідуального творчого стилю викладання предмета за кваліфікацією.

Студент повинен творчо комбінувати підходи до розвитку своїх педагогічних даних, займатися самоосвітою, виробити чітке усвідомлення джерел духовності та завдання збереження світу мистецьких цінностей. Володіти художньою мірою та естетичним смаком у творчості. Аналізувати і оцінювати хід художньо-просвітницької діяльності в своїй галузі, визначати музично-художній, освітній та естетичний рівень учня, розробляти індивідуальні програми музичного та загального розвитку, виявляти особливо обдарованих учнів і спрямовувати їх на подальшу фахову освіту.

Музична освіта за своєю сутністю є психофізіологічним процесом, який спрямовано на виконання творів музичного мистецтва. Тому у значній мірі вона залежить від наявності природних музичних даних фахівця, таких, як: музичні здібності; музичний слух тощо, котрі піддаються розвитку та вдосконаленню.

Успішність підготовки студента-музиканта до педагогічної діяльності спрямована на формування його духовних цінностей, професійно-педагогічної культури, методичної компетентності, інтелектуального розвитку, здатності до рефлексії.

Для ефективної підготовки фахівця визначальною є роль педагога. Його діяльність включає творчо-виконавський компонент, однак, iї специфічною рисою є педагогічна спрямованість. Таке спрямування проявляє себе у накопиченні знань, умінь, навичок у сфері музичного мистецтва та музичної педагогіки для подальшої передачі освітньомистецького досвіду студентам; навчанні, вихованні та особистому і мистецькому розвитку.

Ефективність удосконалення професійної підготовки майбутніх фахівців музичного мистецтва до педагогічно-практичної діяльності 
передбачає визначення закономірностей та принципів такої підготовки, які базуються, у свою чергу, на філософських, педагогічних та мистецьких законах. Знання таких законів дозволяє зробити процес підготовки більш продуктивним і керованим.

Отже, для удосконалення процесу професійної підготовки майбутніх викладачів мистецьких спеціальностей до педагогічної роботи важливим є врахуванням законів всезагального зв'язку, а саме:

- закону детермінації: усі предмети, процеси знаходяться у різних детермінованих зв'язках, відношеннях;

- закону висхідного та низхідного розвитку, що передбачає шлях удосконалення або шлях збідніння, зменшення;

- закону причинності: поява нової якості завжди має причину, одне явище обов'язково породжує інше;

- законів діалектики: закон єдності та боротьби протилежностей, закон переходу кількісних змін у якісні, закон заперечення.

\section{Список використаних джерел:}

1. Вознюк О. В. Загальна теорія систем та їі педагогічні проекції. Професійна педагогічна освіта: системні дослідження : монографія. Житомир : Вид-во ЖДУ ім. І. Франка, 2015. С. 29- 67.

2. Вознюк О. В. Нова постнекласична система мистецької освіти. Актуальні питання мистецької педагогіки. 2016. Вип.5. С. 8-14. 